\author{
J. B. Melekhova ${ }^{1}$ \\ N. Y. Saigushev ${ }^{2}$ \\ O. A. Vedeneyeva ${ }^{3}$
}

\section{TECHNOLOGY OF REALIZATION OF ACADEMIC CONDITIONS OF REFLEXIVE ATTITUDE FORMATION FOR A PROSPECTIVE FOREIGN LANGUAGE TEACHER IN THE COURSE OF PROFESSIONAL TRAINING}

1) Magnitogorsk State Technical University named after G.I. Nosov, 38 Lenin Ave., Magnitogorsk, 455000, Russia

E-mail: melehova.yuliya @mail.ru

${ }^{2)}$ Magnitogorsk State Technical University named after G.I. Nosov, 38 Lenin Ave., Magnitogorsk, 455000, Russia

E-mail: nikolay74rus@mail.ru

3) Magnitogorsk State Technical University named after G.I. Nosov, 38 Lenin Ave., Magnitogorsk, 455000, Russia

E-mail: Vedeneeva12@mail.ru

\begin{abstract}
At the moment, institutions of higher education are responsible to address the essential task of training a teacher with high level of self-comprehension and awareness of his/her /her profession's personal and social importance, who can be responsible for the results of his/her /her professional activities - in other words, have a well-formed reflexive attitude, which will allow him/her to be an active member of professional-and-teaching activities. The strategy of development of professional education reveals the need for training a bachelor of pedagogical education, capable of consciously and effectively carry out professional activities. This situation required the search for new approaches and the development of effective technologies for the professional training of the future teacher of a foreign language. The article presents the authors' technology of realization of pedagogical conditions (actualization of reflexive life experience of a future teacher of a foreign language in situations of pedagogical interaction by means of problem-variable construction of lessons; involvement of the future foreign language teacher in educational professionally-oriented activities through the solution of reflexive and professional tasks; the use of interactive forms of training to work out the reflection algorithm as a means of entering into a reflective position of the future foreign language teacher). The article describes the authors' technology of realization of academic conditions of reflexive attitude formation for a prospective foreign language teacher in the course of professional training, which promotes the effective solution of the above-mentioned task.
\end{abstract}

Key words: reflexive attitude formation; academic conditions; professional training; prospective foreign language teacher. 
ТЕХНОЛОГИЯ РЕАЛИЗАЦИИ ПЕДАГОГИЧЕСКИХ УСЛОВИЙ ФОРМИРОВАНИЯ РЕФЛЕКСИВНОЙ ПОЗИЦИИ БУДУЩЕГО УЧИТЕЛЯ ИНОСТРАННОГО ЯЗЫКА В ПРОЦЕССЕ ПРОФЕССИОНАЛЬНОЙ ПОДГОТОВКИ

1) Магнитогорский государственный технический университет им. Г.И. Носова, ул. Ленина 38, Магнитогорск, 455000, Россия

E-mail: melehova.yuliya@mail.ru

2) Магнитогорский государственный технический университет им. Г.И. Носова, ул. Ленина 38, Магнитогорск, 455000, Россия

E-mail: nikolay74rus@mail.ru

${ }^{3)}$ Магнитогорский государственный технический университет им. Г.И. Носова, ул. Ленина 38, Магнитогорск, 455000, Россия

E-mail: Vedeneeva12@mail.ru

\begin{abstract}
Аннотация. В настоящее время высшая школа ответственна решать актуальную задачу подготовки учителя с высоким уровнем самосознания и осознания личностной и общественной значимости своей профессии, способного нести ответственность за ее результаты, то есть со сформированной рефлексивной позицией, что позволит ему быть активным субъектом профессиональнопедагогической деятельности. Обозначенная стратегия развития профессионального образования выявляет необходимость подготовки бакалавра педагогического образования, способного осознанно и эффективно осуществлять профессиональную деятельность. Такое положение потребовало поиск новых подходов и разработку эффективных технологий профессиональной подготовки будущего учителя иностранного языка. В статье представлена авторская технология реализации педагогических условий (актуализация рефлексивного жизненного опыта будущего учителя иностранного языка в ситуациях педагогического взаимодействия посредством проблемно-вариативного построения занятий; вовлечение будущего учителя иностранного языка в учебную профессионально-ориентированную деятельность посредством решения рефлексивно-профессиональных задач; использование интерактивных форм обучения для отработки алгоритма рефлексии как средства выхода в рефлексивную позицию будущего учителя иностранного языка) формирования рефлексивной позиции будущего учителя иностранного языка в процессе профессиональной подготовки, способствующая эффективному решению выше упомянутой задачи.
\end{abstract}

Ключевые слова: рефлексивная позиция, педагогические условия, профессиональная подготовка, будущий учитель иностранного языка.

Introduction. At the present stage of its evolution, the society is focused on the formation of a XXI century individual who can be an active member of his/her activities. Therefore, the society raises a number of highpriority tasks including the innovation of all aspects of educational policies that address the enhancement of the reflexive potential of education.

By prioritizing state education policies and setting their development strategy and directions, the national doctrine of education in the Russian Federation determines the crucial role played by the teacher in the achievement 
of educational goals and the support of various forms of students' self-management. The Concept of the Federal target program of education development for the 2016-2020 period recognizes the importance of ensuring "the conditions for effective development of Russian education that is focused on forming competitive human potential".

The high-priority tasks defined by the Federal State Standard of Higher Education for training program 44.03.05 "Teachers' Education" (with two profiles) (bachelor's degree) are described as the formation of willingness to realize the social importance of the selected profession, the ability of selfmanagement and self-sufficient vocational training among students, the development of motivated attitude towards teaching activities and individual-and-professional growth planning.

Under such conditions, institutions of higher education need to address the task of training a teacher with a high level of selfcomprehension and awareness of his/her profession's personal and social importance, who can be responsible for the results of his/her professional activities, which will allow him/her to be an active member of professional-and-teaching activities.

The identified strategy of vocational education development reveals the need to train a bachelor of teacher education who can perform his/her professional activities consciously and effectively. It is natural that such a provision required searching for new approaches and developing effective techniques of professional training for a prospective foreign language teacher.

Main part. Studying the reflexive attitude problem with respect to a prospective foreign language teacher as a holistic phenomenon and identifying academic conditions of its effective formation allowed us to develop and to realize the technique of reflexive attitude formation for a prospective foreign language teacher, where the respective conditions were evaluated.

Some fundamental factors of professional training process include educational techniques that ensure integrity and personal and socio- economic practicability. For the purposes of our study, sharing the same point of view with I.F. Isayev, V.A. Slastenin, A.I. Uman, V.P. Bespalko and others, we describe academic techniques as a means and process of communication based on a specific system algorithm of interaction between academic process participants.

The technique of reflexive attitude formation process for a prospective foreign language teacher is based on realizing the following academic conditions:

- actualizing reflexive life experience of a prospective foreign language teacher in a situation of academic interaction by means of problem-and-variable-based structuring of lessons;

- involving a prospective foreign language teacher in profession-oriented activities by solving reflexive-and-professional tasks;

- using interactive forms of education to develop the algorithm of reflexion as a means of reaching the reflexive attitude during professional training of a prospective foreign language teacher.

Effective, relevant and intended formation of any system requires some time. Therefore, the identified academic conditions of reflexive attitude formation for a prospective foreign language teacher must be realized throughout the professional training period.

We worked on the reflexive attitude formation during the professional training of prospective foreign language teachers at the School of Language Studies and Translation (2006-2014), the Institute of History, Philology and Foreign Languages (2014-2016) and the Institute of Humanities in Education (20162017) of the FSBEI of Higher Education "Magnitogorsk State Technical University named after G.I. Nosov" when studying the following professional cycle disciplines under the Federal State Educational Standard for Higher Education (FSES HE): "A practical course in the first foreign language" (1st year), "An introductory audio course" (1st year), "Practical training in acquiring primary professional skills" (2nd year), "A practical course in the culture of verbal communication (first foreign language)" (between 3rd and 5th years), "Intro- 
duction to the theory of intercultural communication" (4th year), "Theory of teaching foreign languages (first foreign language)" (4th and 5th years) and "Teaching practice". The focus and the resources of the described academic disciplines encourage dedicated student involvement in the problem under study and ensure optimum conditions for effective reflexive attitude formation with a prospective foreign language teacher.

The developed practicum on forming a reflexive attitude for a prospective foreign language teacher serves as a key tool for realizing the array of academic conditions. This represents an additional part of the curriculum system of the following professional cycle disciplines under FSES HE: "A practical course in the first foreign language", "An introductory audio course", "Practical training in acquiring primary professional skills", "A practical course in the culture of verbal communication (first foreign language)", "Introduction to the theory of intercultural communication" and "Theory of teaching foreign languages (first foreign language)" and includes reflex-focused practical activities, reflexive tutorials, diagnostic tests of reflexive nature, reflexive portfolio and a teaching practice diary for students from faculties of foreign languages.

Prior to evaluating the technique of realizing academic conditions for the formation of the prospective foreign language teacher's reflexive attitude in practice, teachers from the University's School of the English Language were interviewed to determine the role and the importance of reflexive attitude for prospective foreign language teachers and the need to achieve a higher level of reflexive attitude in the course of professional university training.

Based on the survey findings it was determined that foreign language teachers had a general understanding of the reflexive attitude phenomenon among prospective foreign language teachers and the significance and the relevance of this phenomenon were identified. Thus, the importance and the significance of reflexive attitude formation among prospective foreign language teachers in the course of professional university training was recognized by the majority of the teachers $(85 \%), 5 \%$ of the teachers could not see any point in that and $10 \%$ regarded the fact of reflexive attitude formation positively rather than negatively. Teachers observe the importance of reflexive attitude formation among prospective foreign language teachers in their conscious self-perception as a prospective teacher of this profile, their attitude to the members of academic interaction, the profession of a teacher and the "Foreign language" discipline which, in the best possible way affects, first of all, the quality of the student's foreign language potential, establishes a setting for its further growth, develops selfanalysis, self-cognition and self-improvement abilities and provides focus on further personaland-professional self-development.

The technique of reflexive attitude formation for a prospective foreign language teacher that we have developed represents a reflexive practicum consisting of various tasks, tests and workshops of reflexive nature. The reflexive practicum features the conformity of developed and selected tasks, workshops and tests to the content of the curriculum for FSES HE discipline courses used as a scope for our reflexive attitude formation, which makes it easy to use by foreign language teachers; the presence of improved reflexive portfolio formats of a prospective foreign language teacher and the availability of the teaching practice diary form.

Technique goal: forming a reflexive attitude with a prospective foreign language teacher in the course of professional training.

Technique objectives:

- developing certain personal and professionally important qualities of a prospective foreign language teacher;

- encouraging the development of reflexive abilities of a prospective foreign language teacher;

- ensuring the reflexive focus of language activities during practical training in foreign language;

- providing for reflexive environment which stimulates students' self-cognition and understanding of their actions;

- stimulating the achievement of high degree self-perception as a student from the 
school of foreign languages or a prospective foreign language teacher;

- forming a setting for personal development and improvement of self-perception as a student from the school of foreign languages or a prospective foreign language teacher.

Actualizing reflexive life experience of a prospective foreign language teacher in a situation of academic interaction by means of problem-and-variable-based structuring of studies means creating the required condition for forming his/her reflexive attitude. With regard to the "Practical course in the first foreign language" discipline this condition was fulfilled in the following way. Since, in the context of our study, the reflexive life experience referred to the part of life experience associated with the formation of personal self-awareness of the prospective foreign language teacher during his/her interaction with the society, we believed that the following was necessary first and foremost:

- selecting such problem-related subjects and creating such problematic situations which when discussing them and searching for their solution - enabled the prospective teacher to be fully aware of his/her personal-andprofessional qualities and the nature of his/her academic-and-professional activities with all of its positive aspects and, more importantly, challenges; and to realize his/her real attitude towards the participants of academic interaction (children, colleagues and parents), the profession of a teacher and the specifics of the "Foreign language" discipline;

- providing for authentic and personally relevant context realized by means of maximum consideration of students' needs, interests and personal traits. We provided students with the possibility to select materials on studied subjects, thereby realizing every student's active subjective attitude supported by his/her life experience;

- organizing activities in small groups with the aim to involve every student in the process of foreign-language communication, to create natural environment and to encourage revealing and development of every student's reflexive abilities;

- applying methods and techniques which promote the achievement of reflexive attitude by the student to solve problem-related tasks requiring reflexive activeness which implies personal traits that reveal the interaction between the student's personal ego and the external reality with the purpose to actualize the adaptive potential.

Based on the above we proposed a number of subjects as part of the syllabus for "A practical course in first foreign language" and "A practical course in the culture of verbal communication" - which were basic disciplines throughout the 5-year course - each year while we taught them. The selection of subjects was determined by defining "reflexive attitude" in the context of our study as "a system of conscious attitudes that a prospective foreign language teacher had towards himself as a prospective teacher of foreign language, towards the members of academic interaction, the profession of a teacher and the discipline of Foreign language". This is why the content and the nature of the subjects are linked with the object of the prospective foreign language teacher's personal attitude under formation. This results in the following observed link between the subject content and the objects of the prospective foreign language teacher's personal attitude system under formation: year 1 - personal self-perception as a prospective foreign language teacher; year 2 attitude towards academic and professional activities; year 3 - attitude towards the members of academic interaction; years 4 and 5 - attitude towards the profession of a teacher and the discipline of "Foreign language."

The reflexive life experience of a prospective foreign language teacher in the course of professional training was actualized not only by means of thorough selection of problemrelated subjects for discussion but also by using an array of techniques such as ranking, creative situation development and using incomplete sentences, differences in opinions and discussions.

In the context of the "Appearance and personality of a perfect foreign language teacher" subject the students were offered to listen to some authentic information (a fragment from the "Who am I?" TV show), where four experienced foreign language teachers - including two teachers from the Oxford university and two from private British schools - described 
their opinion on the appearance and the personal-and-professional qualities that a foreign language teacher must have in order to serve as an example for his/her students. Having said that, every teacher had a different point of view, which often conflicted with others. For this reason, when the listening was over, the students were asked to select one of the described points of view or come up with an alternative one. As a result, several points of view were also formed inside the group of prospective foreign language teachers and the image of a perfect foreign language teacher with inherent professional-and-personal qualities was defined at the end of the discussion. As the final step, the students were offered to conduct a self-analysis and to determine whether they possessed such qualities.

Therefore, when solving the set problem the students had to, one way or another, use, firstly, their personal life experience (images of school teachers of foreign languages, tutors and movie and fictitious heroes; identifying positive and negative aspects of their appearance, behavior pattern and professional qualities) and, secondly, their reflexive life experience - the ability to imagine themselves in the place of the teacher they liked, the one whose image was memorized and who generated interest in the professional activities of a teacher.

After fulfilling this condition, the students were offered to imagine themselves in such real-life problematic situations that could be resolved by demonstrating their professional-and-personal traits and assessing themselves as a person who was a student ("I am a student of the School of Foreign Languages") and a person who was a prospective foreign language teacher ("I am a future teacher of foreign language"). Problematic situations were based on the system of psychological exercises.

Students were also offered creative tasks including role playing games where, apart from verbal and cogitative activities, the participants were supposed to demonstrate their reflexive activeness. After some preliminary home-based preparation which ensured effective and thorough actualization of one's personal reflexive life experience students paired up to present (play) dialogues. Then the audience was of- fered to analyze dialogs in terms of appropriateness/ inappropriateness of the selected means of communication, content, manner of presentation, retaining the initiative in communication and the ability of taking up someone's role (i.e. the ability to place oneself in the position of the proposed dialogue characters).

After fulfilling the first academic condition, we actively used such form of education as watching video films which addressed and covered the issues that were important for prospective foreign language teachers. After watching them, the students were offered a number of problem-related tasks.

During the second year, as part of the studied "The secret of successful foreign language learning" and "Choosing a profession" subjects, we offered students to study the articles which had the same headings as the names of the above mentioned subjects and addressed the essence of academic and professional activities of students and teachers at Oxford, Cambridge and Harvard Universities and their opinions on the methods of mastering these types of activities successfully.

After conducting group analysis, discussing the proposed articles and formulating personal points of view, we offered a role-playing game "At the psychologist's". In this game, a volunteer student was picked to play the role of the psychologist who needed to help a group of teenagers (the rest of the group) with choosing their future profession. To do so, he identified the teenagers' systems of values based on the study method suggested by M. Rokich, handed out cards with systems of values (in English) to the "group of teenagers" and asked them to arrange the cards in the order of their importance for them. Then the selected order was checked and the "psychologist" advised the profession to be chosen by any given "teenager".

Prospective foreign language teachers also actualized their reflexive life experience during the reading of the "Daddy-Long-Legs" fiction, by discussing the events which occurred with the young girl. The fictitious heroine who was raised at a British orphan asylum and then studied at one of the prestigious colleges, described her life in letters (representing the reflexion of the principal character) to her guardian, where 
she shared her impressions, emotions and experience associated with different life and studyrelated situations (her learning-and-cognitive activities, communication with peers and relationship with teachers of different disciplines) (please refer to Appendix 7).

Texts for analytical reading and questions for group discussion were offered during the third year when studying "Teachers and students" and "Child-rearing" subjects (please refer to Appendix 8 ). Students were offered to solve a number of problem-related tasks that stimulated the actualization of their personal reflexive life experience and developed reflexive thinking (please refer to Appendix 9).

As part of the "How to become a successful teacher", "Academic success" and "Teaching practice" subjects studied during the $4^{\text {th }}$ year and the $5^{\text {th }}$ year, we provided prospective foreign language teachers with an opportunity to listen to the audio course of lectures on "How to become a successful teacher" by Doctor Wong - a teacher with 28-year professional experience in Central California - where he shared his techniques of involving every student of the class in activities, creating favorable psychological atmosphere, motivating and disciplining students and avoiding any time loss during the lesson as well as some reflexive methods and techniques promoting reflexive activeness during the foreign language lesson. The emotional nature of his speech, informational content and meaningfulness of his lectures stimulated the formation of positive attitude towards the profession of a teacher among the students. The prospective teachers felt the arising wish to appraise the techniques while listening to his lecture. After listening to the course, the students were offered a number of problems for discussion.

When studying the "Teaching Practice" subject the prospective teachers were offered problematic situations for a role-playing game.

The first academic condition was also realized by means of such forms of academicand-professional activities as writing essays and making presentations in subjects that were important for a prospective foreign language teacher, in English (during years 1-5).
It should be worth noting that all the above-listed methods and forms of organizing practical English classes are focused on actualizing reflexive life experience of students, i.e. the prospective foreign language teachers.

The second condition - involving a prospective foreign language teacher in professionoriented activities by solving reflexive professional tasks - was also realized when studying the same subjects during the classes of FSES $\mathrm{HE}$ disciplines throughout the professional training period.

Practical foreign language classes, together with linguistic communication activities organized in active and interactive environment, were at different stages (at the beginning, in the middle or at the end of the lesson or at the beginning, in the middle or at the end of a certain activity during the class) accompanied by creative tasks of reflexive nature which were based on reflexive professional task classification.

We have selected an array of tasks, tests, questionnaires, games and workshops used to include reflexive professional tasks in the process of professional training applied to students, i.e. prospective foreign language teachers.

It is important to note that the students solved such tasks both throughout their profession-oriented activities and at each stage of every lesson of any above-mentioned discipline. Thus, during the $1^{\text {st }}$ year, we arranged an introductory lesson "What do you want? Hopes and fears" to every group. The students were shown numbered pictures of people from different age groups and careers with the same number of numbered "thought" statements given by those people (please refer to Appendices 11-12). The students were asked to guess which thought belonged to one or another person. Then they would listen to the audio record of thought statements and check whether they guessed them correctly.

Naturally, one of the statements ("How to find the best way of communicating with this group of naughty children and make them interested in language studies?") belonged to a teacher. This particular fact allowed to question the students about what they wanted in life and to receive a variety of answers. It is noteworthy that all the students explained their enrollment 
at the school of language studies and translation by the desire to study a language and most of them expressed the desire to be a foreign language teacher. Nevertheless, a small percentage found it difficult to answer the posed question, which triggered to perform some additional exercises (Appendices 12 and 14).

Systematic performance of a simple exercise ("What stage am I at as a student and as a prospective foreign language teacher?") assisted the prospective foreign language teachers in completing the task on forming appropriate self-appraisal. Students were handed out sheets with drawn seven-step stairs and offered to depict themselves standing on the step where, according to them, they belonged as prospective teachers at that time. After the students made their choice, the teacher explained the meaning of the steps. Discussing the reasons for borderline results and the ways to achieve the appropriate level of self-appraisal represented an important stage.

Another technique which realizes the second condition is a projective drawing "I am what I am" that triggers the formation of objective self-appraisal as a subject of learning-andprofessional activities (years 1-3) and a subject of professional activities (years 4-5, when the students - prospective teachers - start dealing with the practice of conducting foreign language classes at workshops on language teaching methods applied at school) among the students - prospective teachers. Students - prospective foreign language teachers - make sure that nobody can see them drawing themselves. Then the drawings are collected and mixed together. Students exchange their impressions about each drawing. In other words, they describe individual traits of the people in the drawings and are suggested to guess which student is depicted in any particular drawing.

Therefore, the described exercises, games and questionnaires represent "realizers" of a group of reflexive professional tasks focused on the formation of positive and proper selfperception as a subject of learning and profession-oriented activities; on recognizing and identifying personal interests, needs, motives and values, individually personal and professionally important traits, abilities and capabili- ties; on achieving compatibility between the conative value-based system and the array of individually personal and professionally important traits, abilities and capabilities; on fulfilling the perfect self-image of a student from the school of foreign languages and a foreign language teacher; on correlating personal needs, motives, interests and values with those of the communicating partners and with the perfect conative value-based system established in the society; on correlating one's own personal and professionally important traits, abilities and capabilities with those found in the perfect image of a foreign language teacher; on independent analysis of personal needs, motives, interests and values; identifying principal interests, needs, motives and values; determining the type of personal motivation towards learning and profession-oriented activities; and on independent analysis and identification of one's most important individually personal and professional traits, abilities and capabilities.

The following group of reflexive professional tasks (oriented towards the formation of positive proper attitude towards the profession of a teacher) was offered by us through an array of reflexively oriented procedures, games and exercises; surveys of reflexive nature; and the performance of reflexive tasks before, during and after watching feature films and cartoons ("Angel-A", "The King's Speech”, "Dead Poets Society", "Brother Bear", "1+1", The Ron Clark Story", "Lecture 21", "School of Rock", "The Perfect Teacher", "A Dangerous Profession", "The Chorus" and "Dangerous Minds").

The technique of realizing the third condition is based on using interactive teaching methods which stimulate practicing the reflexive action algorithm and enable to achieve the reflexive attitude - we establish the internal structure of the reflexive act. The technique consists of the following three stages:

1. Stopping any subject-related (learning and profession-oriented) activities related to the "Foreign Language" discipline. Any preformed linguistic activities regarding this discipline are either ended or paused. The attention of prospective foreign language teachers is fully focused on the expected activity analysis. 
2. Restoring the sequence of performed actions. Students - the prospective foreign language teachers - are offered to describe all their actions during the performance of reflexion activities (in verbal or written form).

3. Exploring the observed sequence of actions: how effective and productive it is and the extent to which it matches with set goals and objectives. The teacher suggests parameters for reflexive analysis. Students can determine the parameters themselves based on learning and profession-oriented purposes.

4. Identifying and formulating the outcome of reflexion: ideas, suggestions and answers to the questions related to the content of academic and professional activities; techniques and ways of proceeding; suggestions on academic and professional activities performed in the future and proposals for improving their quality.

5. Testing all the hypotheses in practice as part of academic and professional activities.

The subject of discussions, debates and workshops in the form of interactive teaching methods included cognitive self-image as a "prospective foreign language teacher", academic and professional activities, participants of academic interaction and the "Foreign language" discipline. Every professional training course included a particular form of conducting lessons which was used in the syllabus of FSES HE disciplines, such as "A practical course in first foreign language", "An introductory audio course", "A practical course in the culture of verbal communication", "Theory and principles of teaching foreign languages", "Practical training in acquiring primary professional skills" and "Teaching practice".

Conclusion. The technique of realizing academic conditions for reflexive attitude formation among prospective foreign language teachers is based on the principles of consistency, the member of activities, determinism, development, flexibility, implicitness and feedback and includes the use of specially selected reflexive methods, techniques, forms and means of education during practical foreign language courses, workshops and lectures, in the course of conducting research and development and during the teaching practicum un- dertaken by prospective foreign language teachers.

Информация о конфликте интересов: авторы не имеют конфликта интересов для декларации.

Conflicts of Interest: the authors have no conflict of interests to declare.

\section{References}

1. Bespalko, V.P. (1989), Slagaemyie pedagogicheskoy tekhnologiy [Components of the academic technique], Prosveshcheniye, Moscow, Russia.

2. Brockbank, A. and McGill, I. (2000), Facilitating reflective learning in higher education, SRHE\&OUP, Buckingham, UK.

3. Brookfield, S.D. (1995), Becoming a critically reflective teacher, Jossey-Bass, San Francisco, USA.

4. Green, A. (2011), Becoming a Reflective English Teacher, Open University Press, McGrawHill Education, McGraw-Hill House.

5. Henke, N.R. Reflective teaching (Electronic source), Available at: http//www.disal.com.

6. Hole, S. \& McEnte. (1999), Reflection is at the heart of practice, Educational Leadership.

7. Isayev, I.F. (2004), Professionalnopedagogycheskya kultura prepodavatelya [Professional-and-academic culture of a teacher], Akademiya, Moscow, Russia.

8. Korthagen Fred, A.J. (2001), Linking practice and theory. The Pedagogy of realistic teacher education, Lawrence Erlbaum Associates Publishers, Mahwah, New Jersey, USA.

9. Moon, J. (2000), Reflection in learning \& professional development, Kogan Page, London, UK.

10.Osterman, K.F. (1990), Reflective Practice: A new agenda for education, Education and Urban Society.

11.Risko, V.J., Vukelich, C. and Roskos, K. (2002), Preparing teachers for reflective practice: Intentions, contradictions, and possibilities, Language Arts Journal.

12.Seifert, K.L. (2001), Reflective thinking and professional development, Houghton Mifflin, Boston, USA.

13.Schón, D. (1991), The reflective practitioner Jossey-Vass, San Francisco, USA

14.Slastenin, V.A. and Kashirin V.P. (2001), Psykhologya i pedagogika [Psychology and education], Akademiya, Moscow, Russia. 
15.Uman, A.I. (1999), Tekhnologicheskiy podhod $k$ obuchenyu: teoreticheskyie osnovy [Process approach to education: theoretical basis], Oryol, Russia.

\section{Данные авторов:}

Мелехова Юлия Борисовна, кандидат педагогических наук, старший преподаватель кафедры английского языка

Сайгушев Николай Яковлевич, доктор педагогических наук, профессор кафедры педагогики

Веденеева Ольга Анатольевна, кандидат педагогических наук, доцент кафедры педагогики.

\begin{abstract}
About the authors:
Julia Borisovna Melekhova, Cand. of Sciences (Pedagogy), Senior Teacher, Department of the English Language and Theory of Teaching Foreign Languages

Nikolay Yakovlevich Saygushev, Doctor of Sciences (Pedagogy), Professor, Department of Pedagogy

Olga Anatolievna Vedeneeva, Cand. of Sciences (Pedagogy), Senior Lecturer
\end{abstract}

